\title{
LOGISTIC TRANSPORT MODEL OF REGION-SCALE DISTRIBUTION OF ORGANIC FERTILISERS
}

\author{
Roman Uvarov, Alexander Briukhanov, Ekaterina Shalavina \\ Institute for Engineering and Environmental Problems in Agricultural Production, Russia \\ rauvarov@gmail.com, sznii@yandex.ru, shalavinaev@mail.ru
}

\begin{abstract}
Environmental safety of livestock and poultry waste handling may be achieved through optimal transportation and distribution of resulting organic fertilisers between the consumers - crop-growing farms. With this aim in view, a logistic transport model was created with due account for fertilising quality and ecologically grounded application rates of organic fertilisers. The model was applied to agricultural enterprises of Leningrad Region, where 121 cattle, 15 pig and 14 poultry complexes are located (as of 2015), with more than 5 million tons of animal and poultry manure being produced annually. The model allowed identifying 34 agricultural enterprises as organic fertiliser suppliers and 124 agricultural enterprises as organic fertiliser consumers. The transport problem of linear programming was solved by the method of potentials by the software written in Fortran using the calculated correction factors of nitrogen content in one cubic meter of organic fertilisers: 0.5 for cattle enterprises, 1 - for pig-rearing complexes, and 0.34 - for poultry complexes. The model allowed distributing all produced organic fertilisers on the fields of crop growing farms with the minimal transportation costs. The model was verified on the data from an egg poultry factory with the stock of 579.1 thousand head and the annual poultry manure yield of 26.8 thousand tons and the pig complex with the stock of 17.5 thousand head and the annual manure yield of 71.9 thousand tons. The achieved savings were 19,251 thousand roubles (282.4 thousand Euros) and 93,117 thousand roubles (1365.4 thousand Euros), respectively.
\end{abstract}

Key words: environmental safety, manure utilisation, logistic model, transportation.

\section{Introduction}

State program for development of agriculture for 2013-2020 sets the tasks to produce ecologically safe agricultural products through regulated agricultural use of land, water and other renewable natural resources and the improvement of soil fertility. The latter may be achieved by increasing the humus content to the optimum value. The main source of humus replenishment in soil is organic fertilisers produced from animal and poultry manure.

The 90's of the twentieth century witnessed the break of links between livestock and crop farms, resulting in spot accumulation and overabundance of raw material for organic fertiliser production. Unused livestock waste is placed on agricultural land with significant negative impact on the environment. Therefore, the proper management of secondary resources produced in agro-industrial sector, more specifically, calculation of the optimal routes of their distribution across the region, is one of the priorities to ensure clean and safe environment [1].

Many scientists devoted their efforts to solve this problem; however, there is still no general universal scheme that would allow to create an objective assessment for possibilities of using certain manure transportation techniques under conditions of specific regions [2-4].

In order to reduce the environmental pressure from livestock and poultry enterprises and to substantiate the efficient processing and subsequent application of organic waste, a logistic model was designed, which creates the optimal transportation and distribution pattern of organic fertilisers produced from animal/poultry manure under conditions of a particular region with due account for the fertiliser nitrogen and the needs of agricultural enterprises.

\section{Materials and methods}

As the soils of the North-Western Federal District (NWFD RF) of the Russian Federation have a low humus content and shortage of nutrients, the main use of animal/poultry manure is its processing and fertilising application [5].

In the study, Leningrad Region was considered as a pilot region, being the economic leader in NWFD RF. It has favourable natural and climatic conditions and sufficient resource potential for the production of high-quality livestock products. Here 121 large-scale cattle, 15 pig and 14 poultry complexes are located, where around 5000 thousand tons of animal/poultry manure are produced annually. 
The study was based on the outcomes of our previous research [6].

To estimate the potential for manure use as a raw material for organic fertiliser production, the mass and nutrient content of animal/poultry manure produced on each large-scale livestock/poultry enterprise were calculated. Organic fertiliser samples from 75 enterprises were analysed in the laboratory in terms of total nitrogen content: $0.48 \%$ in fertilisers from cattle manure, $0.24 \%$ in fertilisers from pig manure, and $1.4 \%$ in fertilisers from poultry manure. Taking into account HELCOM recommendations ( $\left.170 \mathrm{~kg} \mathrm{~N} \cdot \mathrm{ha}^{-1}\right)$ and the total area of agricultural land, the potential of the land use for produced organic fertiliser spreading was estimated for each district in the region (Table 1) [6-8]. The data in Table 1 take into account the transportation of organic fertilisers from the supplier to consumer within one district of Leningrad Region.

Table 1

Amount of total nitrogen in produced animal/poultry manure in the districts of Leningrad region and the reserves of agricultural land

\begin{tabular}{|l|c|c|c|c|}
\hline \multirow{2}{*}{ District } & \multicolumn{2}{|c|}{ Produced manure nitrogen, t } & $\begin{array}{c}\text { Reserve (+) and shortage (-) of } \\
\text { agricultural land for organic } \\
\text { fertiliser spreading, ha }\end{array}$ \\
\cline { 2 - 5 } & $\begin{array}{c}\text { Cattle } \\
\text { farms }\end{array}$ & Pig farms & $\begin{array}{c}\text { Poultry } \\
\text { complexes }\end{array}$ & +429 \\
\hline Boksitogorskij & 37.5 & 0.8 & & +23029 \\
\hline Volosovskij & 1468.5 & & & +5612 \\
\hline Volkhovskij & 678.8 & 64.5 & & +1917 \\
\hline Vsevolozhskij & 580.1 & 144.7 & 536 & -11230 \\
\hline Vyborgskij & 663.4 & 3.8 & 3894 & +1058 \\
\hline Gatchinskij & 1060.5 & 465.8 & 4676 & +11022 \\
\hline Kingiseppskij & 617.6 & & & +4348 \\
\hline Kirishskij & 360 & & & -43643 \\
\hline Kirovskij & 61.5 & & 12364 & +2014 \\
\hline Lodejnopol'skij & 118.1 & 18.6 & & +6109 \\
\hline Lomonosovskij & 533.3 & 34.8 & 1056 & +15122 \\
\hline Luzhskij & 987.8 & 18.4 & & +1839 \\
\hline Podporozhskij & 34.5 & & & +5261 \\
\hline Priozerskij & 1050.8 & 149.6 & & +4690 \\
\hline Slantsevskij & 276.4 & & & +5955 \\
\hline Tikhvinskij & 391.1 & & & +5845 \\
\hline Tosnenskij & 913.5 & 1128.6 & & +39377 \\
\hline TOTAL & 9833.4 & 2029.6 & 22526 & \\
\hline
\end{tabular}

Table 1 shows that throughout Leningrad Region, only two districts have a shortage of land for spreading of all animal/poultry manure produced on their territory: Vyborgskij District (11230 hectares) and Kirovskij District (43643 hectares).The rest of the districts have enough land for this purpose. In general, Leningrad Region has 39377 hectares' reserve suitable for application of processed animal/poultry manure.

To substantiate the optimal distribution of organic fertilizers, the transport problem of linear programming was applied using correction factors, which take into account the nitrogen content in one cubic meter of organic fertilisers: 0.5 - for cattle enterprises, 1 - for pig-rearing complexes, and 0.34 for poultry complexes. The transport problem was solved by the method of potentials by the software written in Fortran.

Solution to this problem is essentially a search for values of unknown organic fertilizer masses that comply with set limitations and result in minimal function values. There are different methods to solve linear programming problems, the most common of which are the simplex method [9], modified simplex method etc. There are also different specialized software applications for this purpose, and you can solve these problems in MS EXCEL as well [10].

The transport problem model has 3 groups of linear relations: the first group describes the objective of the problem, the second group presents limitations for variables, and the third group states 
that variables should not be negative. The main constructive feature of this model is its balance in terms of resource presence and requirements.

During model construction it is important to pay attention to dimensions of all the included values. All the limitations should be defined in the same dimensions, and these dimensions should be used variables, while dimensions of the target function coefficients should correspond to dimensions of variables in this function.

\section{Results and discussion}

To create the logistic transport model the mass of total nitrogen in the resulting organic fertiliser was calculated for each livestock/poultry enterprise. When identifying the fertiliser suppliers, it was taken into account that, if the farm consumes more nutrients than are available in the produced manure, then such a farm is excluded from the list of suppliers, and its nitrogen requirements are adjusted by the amount from its own production. The mass of total nitrogen in the resulting organic fertiliser was recalculated based on available agricultural land.

Calculations were based on the mass of produced/consumed total nitrogen in organic fertilisers. For each nitrogen supplier (livestock/poultry enterprise), the consumers (crop growing farms, on the fields of which the organic fertilisers are applied) were identified. All in all 34 organic fertiliser suppliers and 124 consumer enterprises were identified.

The structured economic and mathematical model of the transport problem may be presented as follows:

$$
\sum_{i=1}^{m} \sum_{j=1}^{n} C_{i j} X_{i j} \rightarrow \min
$$

Under conditions:

$$
\begin{gathered}
\sum_{j=1}^{n} X_{i j}=A_{i}(i=1,2, \ldots, m), \\
\sum_{i=1}^{m} X_{i j}=B_{j}(j=1,2, \ldots, n), \\
\sum_{i=1}^{m} A_{i}=\sum_{j=1}^{n} B_{j},
\end{gathered}
$$

where $m$-number of suppliers of total nitrogen in organic fertiliser;

$n$ - number of consumers of total nitrogen;

$A_{i}$ - mass of produced total nitrogen in the $i$-th object;

$B_{j}$ - mass of consumed total nitrogen by the $j$-th object;

$C_{i j}$ - transportation cost of 1 tone of total nitrogen the $i$-th object-supplier to the $j$-th object-consumer;

$X_{i j}$ - mass of total nitrogen delivered from each supplier to each consumer.

To solve the transport problem of linear programming, the following condition should be observed: the mass of produced (supplied) total nitrogen must be equal to the mass of consumed total nitrogen. In our case, the produced amount is 24552 tons of nitrogen, and consumed amount is 30108.2 tons of nitrogen, that is, the consumption exceeds the supply. To meet this condition, an additional (conditional) $35^{\text {th }}$ supplier with the mass of 5556.2 tons of nitrogen was introduced. For the overall mass of total nitrogen in the organic fertilisers to be distributed among nearby crop growing farms, the distance from the conditional $35^{\text {th }}$ supplier to each crop farm was set at $100,000 \mathrm{~km}$.

The developed model, unlike other similar models, accounts not only for the transportation distance of obtained organic fertilizers, but also for the total nitrogen content in the transported fertilizers. 
The scheme of the transport problem solution by the example of agricultural enterprises in Leningrad Region is shown in Figure 1 (values on the map show nitrogen mass in transported organic fertilizers).

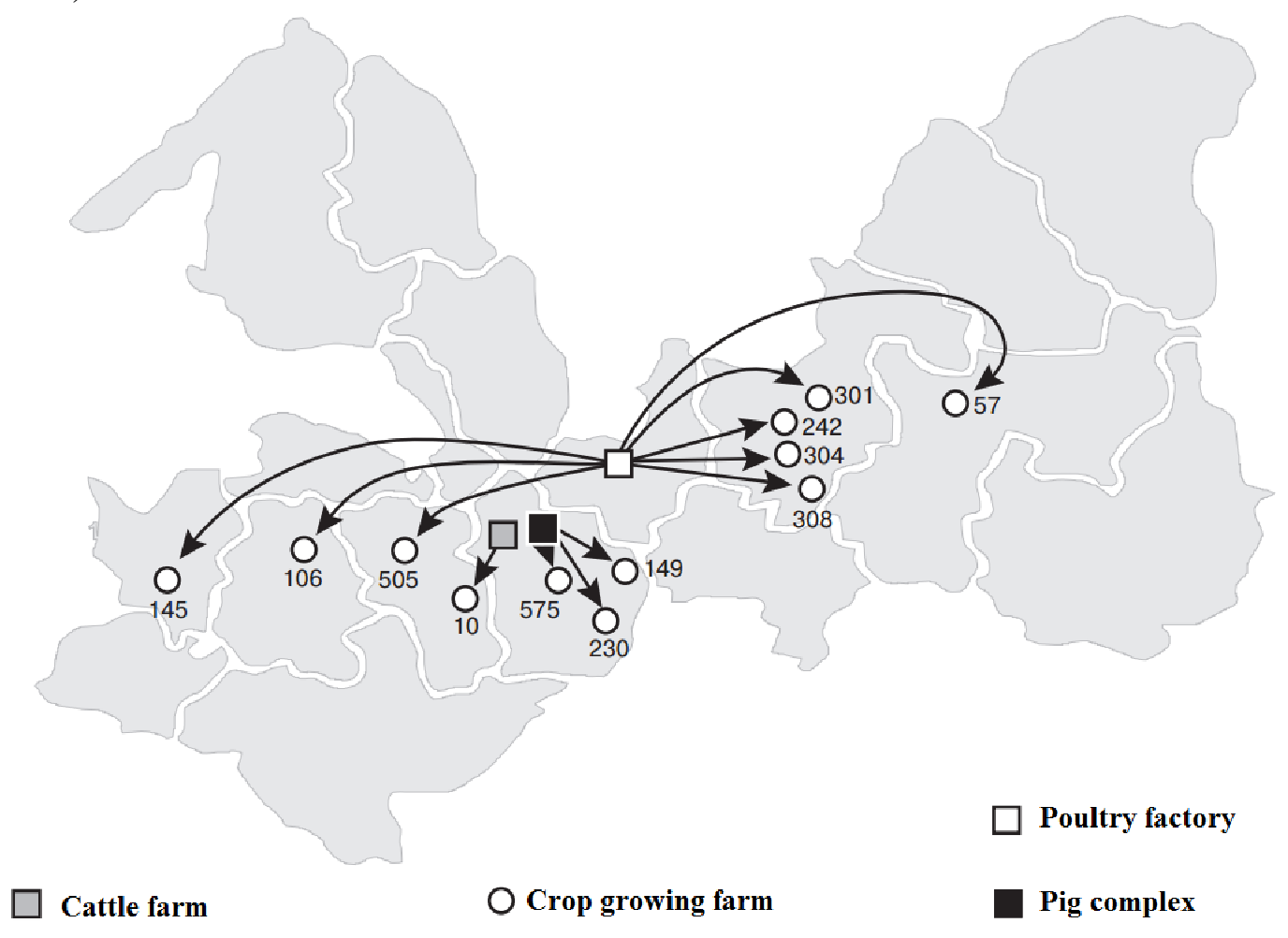

Fig. 1. Schematic presentation of transport problem solution by example

Using the created model, a logistic scheme for distribution of organic fertilisers was created with due account for environmental standards and the average transportation distance of organic fertilisers for each of the supplying enterprises was determined. For cattle enterprises it was found to be $15.3 \mathrm{~km}$, for pig complexes $-26.2 \mathrm{~km}$ and for poultry factories $-78 \mathrm{~km}$.

The created model also allowed to identify the districts in Leningrad Region with the deficit in organic fertilisers - the areas, which received the conditional organic fertiliser from the $35^{\text {th }}$ supplier. The land reserves for spreading of processed animal/poultry manure in these districts are distributed as follows: $59 \%$ of the total land reserves are found in Luzhskij District, $19 \%$ - in Slantsevskij District, $16 \%$ - in Kingiseppskij District, and $1 \%$ - in Boksitogorskij District. These districts are considered favorable for the construction of new livestock/poultry enterprises or for capacity expansion of the existing enterprises: here it is permissible to increase the number of animals up to 50 thousand livestock units, provided the environmental requirements are observed.

To estimate the benefits of the created model application the performance of selected agricultural enterprises was considered with and without the use of the modelled logistic pattern of organic fertiliser transportation.

The main ecological and economic criterion was the economic effect calculated by the formula (5):

$$
E=P+S-T-Z-F,
$$

where $E$-economic effect, thousand roubles;

$P$ - profit from the sale of organic fertiliser, thousand roubles;

$S$ - farm subsidies, thousand roubles;

$T$ - fees for negative impact on the environment (placement of waste), thousand roubles;

$Z$ - processing costs of animal/poultry manure into organic fertilisers, thousand roubles;

$F-$ transportation costs of organic fertilisers, thousand roubles. 
Let $Q_{1}$ be the mass of animal/poultry manure produced on the farm per year $(t)$, and then $Q_{2}$ is the mass of manure-based organic fertiliser produced per year $(t)$.

In this case, the profit from the sale of organic fertilizer is determined by the formula (6):

$$
P=X \cdot Q_{2} \cdot P_{1},
$$

where $X-$ share of the total organic fertiliser produced to be sold (non-dimensional);

$P^{1}-$ cost of one ton of organic fertiliser, thousand roubles.

If the farms have introduced intensive and environmentally friendly technologies for processing and application of animal/poultry manure and use all the resulting organic fertilisers to improve the soil fertility, the legislation of the Russian Federation provides for subsidies for such farms. The subsidy size is determined by the formula (7):

$$
S=Q_{1} \cdot S_{1},
$$

where $S_{1}$ - average subsidy rate in the North-West Federal District, rouble per ton.

The fee for the negative impact on the environment (placement of waste) is determined by the formula (8):

$$
T=Y \cdot Q_{2} \cdot T_{1},
$$

where $Y$-share of organic fertiliser, accumulated on agricultural lands (non-dimensional);

$T_{1}$ - fee for the placement of Hazard Class III waste (poultry manure, pig manure), thousand roubles per ton.

The processing costs of poultry and pig manure into an organic fertilizer were determined by the formula (9):

$$
Z=Q_{1} \cdot Z_{1},
$$

where $Z_{1}$ - processing costs of animal/poultry manure according to the technology in place, thousand roubles per ton.

The transportation costs of organic fertilisers to the place of use (agricultural land of the consumer) were determined by the formula (10) with due account for the trips of vehicles to the fields and back:

$$
F=A \cdot Q_{2} \cdot F_{1} \cdot 2 \cdot R,
$$

where $A-$ share of organic fertiliser to be transported (non-dimensional);

$F_{1}$ - transportation costs of organic fertilisers, rouble per ton per km;

$R$ - one-way transportation distance, $\mathrm{km}$.

The economic effect was calculated for the egg poultry factory with the stock of 579.1 thousand head and the annual poultry manure yield of 26.8 thousand tons (22.2 thousand tons of ready organic fertiliser).

If the poultry farm does not have a reasonable logistic scheme of organic fertilisers transportation in place, then

- half of the fertilisers produced is spread on the nearby agricultural land, while the rest is stored on the storage sites, causing significant harm to the environment;

- state subsidies are not allocated $(S=0)$.

- annual profit from the sale of organic fertiliser produced potentially may be $P=1110$ thousand roubles;

- for one year accumulation of poultry manure the poultry factory will have to pay $T=13320$ thousand roubles;

Depending upon the selected processing technology of poultry manure into organic fertilisers the specific costs were calculated (Table 2) [11-14]. 
Economic indicators of different processing technologies for poultry manure

\begin{tabular}{|l|c|c|}
\hline \multirow{2}{*}{ Technology } & \multicolumn{2}{c|}{ Specific costs, rouble per ton } \\
\cline { 2 - 3 } & Capital & Operational \\
\hline Long-term storing (maturing) & $1490-2630$ & $190-450$ \\
\hline Passive composting in clamps & $1155-1480$ & $325-355$ \\
\hline Active composting in clamps & $930-1090$ & $445-505$ \\
\hline Biofermentation in chamber-type fermenters & $1050-1210$ & $395-440$ \\
\hline Biofermentation in drum-type fermenters & $1780-2220$ & $550-595$ \\
\hline Tunnel drying & $19115-31860$ & $7010-9560$ \\
\hline Tunnel drying with subsequent pelleting & $22300-35050$ & $7650-10200$ \\
\hline Drum drying with subsequent pelleting and batch combustion & $44500-66700$ & $4500-6700$ \\
\hline
\end{tabular}

On the poultry factory under consideration, the manure is processed into organic fertiliser by passive composting. So, the processing costs of all the poultry manure produced per year are $Z=26800$ thousand roubles.

Transportation costs of organic fertilisers to the fields for spreading will be $F=555$ thousand roubles, taking into account the trips to the fields and back.

Economic effect for the selected poultry factory without the modelled logistic pattern of organic fertiliser transportation is estimated in $E=-39565$ thousand roubles per year.

If the poultry factory applies the modelled logistic pattern of poultry manure-based organic fertiliser transportation and subsequent field spreading with the aim to improve the soil fertility, the poultry factory will sell all the organic fertiliser produced to be spread on the consumer's fields. In this case, the potential sales profit will be 2220 thousand roubles per year.

Besides, the poultry factory will be entitled to the state subsidies at the rate valid for NWFD RF. These subsidies for the poultry factory under consideration will amount to $S=8040$ thousand roubles.

If the poultry factory sells all the processed poultry manure, it does not need to pay for the placement of Hazard Class III waste, therefore, $T=0$.

The processing costs of all the manure produced by passive composting are 26800 thousand roubles per year.

The average transportation distance of organic fertilisers $R$ for this poultry factory, calculated using the created logistic model, is $34 \mathrm{~km}$. Consequently, the transportation costs of all the fertilisers to the consumer's fields will amount to 3774 thousand roubles, taking into account the trips of vehicles there and back.

Economic effect for the selected poultry factory with the modelled logistic pattern of organic fertiliser transportation is estimated in $E=-20314$ thousand roubles per year. It means the poultry factory may have an annual economy of 19251 thousand roubles.

The created model was also tested on the pig complex with the stock of 17. 5 thousand head and the annual manure yield of 71.9 thousand tons (64.7 thousand tons of organic fertilisers after manure processing).

Economic effect for the selected pig complex without the modelled logistic pattern of organic fertiliser transportation was estimated in $E=-207060$ thousand roubles per year; that with the modelled logistic pattern of organic fertiliser transportation was estimated in $E=-113943$ thousand roubles per year. The annual economy for the pig complex under consideration may be 93117 thousand roubles per year.

\section{Conclusions}

1. In the current agricultural context, when about $70 \%$ of livestock enterprises do not have enough land to utilise the manure produced, the search for and establishment of transport links between the livestock and crop growing farms is an effective way to reduce the environmental pressure.

2. Analysis of livestock and crop sectors of the agro-industrial complex of Leningrad Region allowed estimating the agricultural land reserve in each district for the application of the produced 
organic fertilisers. Thirty four agricultural enterprises were identified as organic fertiliser suppliers and 124 agricultural enterprises were identified as organic fertiliser consumers.

3. On the basis of the data obtained, a logistic model of organic fertilisers transportation was created. To develop the model a transport problem of linear programming was applied. To have equal masses of the supplied and consumed organic fertiliser nitrogen, a conditional $35^{\text {th }}$ supplier of organic fertilisers with a nominal fertiliser nitrogen mass of 5556 tons per year was introduced.

4. The created model allowed determining:

- routes and average distances of organic fertiliser transportation from suppliers to consumers;

- districts with agricultural land reserve for application of organic fertilisers produced in other districts in Leningrad Region.

5. The optimisation criterion of the model was the economic effect, which included the sales profit of organic fertilisers, state subsidy, environmental fee for the negative impact, manure processing costs, and the resulting organic fertiliser transportation costs.

6. Application of the created model to the conditions of selected poultry factory and pig complex located in Leningrad Region may result in annual saving of 19251 thousand roubles and 93117 thousand roubles, correspondingly.

\section{References}

[1] Суровцев В.Н., Бильков В.А., Никулина Ю.Н. Инновационное развитие молочного животноводства на Северо-западе РФ как основа повышения конкурентоспособности производства молока (Innovation Development of Dairy Cattle Breeding in the North-West of the Russian Federation as the Basis for Enhancing the Competitiveness of Milk Production). Economic and Social Changes: Facts, Trends, Forecast. 2013. No 4 (28). pp. 143-150. (In Russian).

[2] Ghafoori E., Flynn P.C., Feddes J.J. Pipeline vs. Truck Transport of Beef Cattle Manure. Biomass and Bioenergy. 2007. Vol. 31, Issues 2-3, pp. 168-175.

[3] Priekulis J., Vartukapteinis K., Melece L. Costs of Liquid Manure Transportation and Incorporation Using Mobile Transport Aggregates. Proceedings of $16^{\text {th }}$ International Scientific Conference "Engineering for Rural Development", May 24-26, 2017, Jelgava, Latvia. pp. 1474-1479.

[4] Garbs M., Geldermann J. Analysis of Selected Economic and Environmental Impacts of Long Distance Manure Transports to Biogas Plants. Biomass and Bioenergy. 2018. Vol. 109, pp. 71-84.

[5] Синицына С.М., Архипов М.В., Данилова Т.А. Потенциал производства продукции растениеводства в Северо-Западном федеральном округе (Crop Production Potential in the North-West Federal District). Journal "Izvestia of Timiryazev Agricultural Academy". 2017. No. 4. pp. 114-136. (In Russian)

[6] Брюханов А.Ю., Шалавина Е.В. Анализ образования и накопления животноводческих отходов в Ленинградской области (Analysis of Generation and Accumulation of Livestock Waste in Leningrad Region). Proceedings of scientific and practical conference "Environmental problems of organic fertiliser application in arable farming". Vladimir, Russia, June 8-10, 2015. pp. 310-317. (In Russian)

[7] HELCOM Recommendation 28E/4. Adopted 15 November 2007 having regard to Article 20, Paragraph $1 \mathrm{c}$ ) of the Helsinki Convention. Amendments to Annex III "Criteria and Measures Concerning the Prevention of Pollution from Land-Based Sources" of the 1992 Helsinki Convention. [online] [14.02.2018] Available at:

http://helcom.ru/helcom_documents/recommendations

[8] Unified Interdepartmental Information-Statistical System (UIIS). [online] Available at: https://www.fedstat.ru/ [12.02.2018].

[9] Вентцель Е.С. Исследование операции. М.: Soviet radio, 1972. 552 p. (In Russian)

[10]Валге A.M. Исследование систем EXCEL и Matcad при проведении исследований по механизации сельскохозяйственного производства. ГНУ СЗНИИМЭСХ. СПб.: 2013. 200p. (In Russian) 
[11]Ковалев Н.Г, Барановский И.Н. Органические удобрения в XXI веке: биоконверсия органического сырья (Organic Fertilisers in the XXI Century: Bioconversion of Organic Material). Tver, ChuDo Publishers, 2006, 304 p. (In Russian).

[12] Хмыров В.Д., Гурьянова Ю.В., Куденко В.Б., Труфанов Б.С. Технология приготовления органических удобрений и внесение в почву (Technology of Preparation of Organic Fertilizers and Soil Application) // Bulletin of Michurinsk State Agrarian University. 2013. No 6. pp. 55-59. (In Russian).

[13]Васильев Э.В. Обоснование рационального радиуса транспортировки органических удобрений (Basis of the Rational Radius of the Manure Transportation). Molochnokhozyaistvenny Vestnik. 2014. No 1 (13), pp. 49-55.

[14]Briukhanov A.Y., Vasilev E.V., Shalavina E.V., Kucheruk O.N. Engineering Solutions of Environmental Problems in Organic Waste Handling. IOP Conference Series: Earth and Environmental Science [online] [11.01.2018] Available at:

http://iopscience.iop.org/article/10.1088/1755-1315/87/4/042001/pdf. 